\title{
Simple Application of Time Correlated Single Photon Counter of Picosecond Pulsed Laser to Measure Refractive Index of Saline Solution
}

\author{
Isnaeni ${ }^{1, a, *}$, Reynaldi Gilang Mulyawan ${ }^{2, b}$, and Ahmad Reza Hakimi ${ }^{2, c}$ \\ ${ }^{1}$ Research Center for Physics, Lembaga Ilmu Pengetahuan Indonesia \\ Building 440-442, Puspiptek, South Tangerang, Banten 15314, Indonesia \\ ${ }^{2}$ Department of Electrical Engineering, Faculty of Electrical Technology, Isntitut Teknologi Sepuluh Nopember \\ Sukolilo, Surabaya 60111, Indonesia
}
e-mail: a isnaeni@lipi.go.id, ${ }^{b}$ rgmul@protonmail.com, and ${ }^{\mathrm{c}}$ ahmadrezahakimi23@gmail.com
* Corresponding Author

\begin{abstract}
Time correlated single photon counter was design for measuring fluorescence lifetime of emitting materials. It was designed for photonics basic research and science that is usually done in a laboratory. Furthermore, time correlated single photon counter can be used to measure simple and more practical optical properties of materials, such as refractive index. However, since the system was not designed for this practical application, a simple setup modification and calculation is required. In this work, time correlated single photon counter is utilized to measure the refractive index of sodium chloride solutions. The measurement was done using simple time of flight calculation of each pulse of picosecond pulsed laser. Our measurement was done on different concentrations of sodium chloride that have different refractive indices. It was found that the measurement technique and calculation was able to produce consistent quantitative calculation of refractive indices.
\end{abstract}

Keywords: time of flight, picosecond pulsed laser, refractive index

\section{Aplikasi Sederhana Time Correlated Single Photon Counter dari Laser Pulsa Picosekon untuk Mengukur Indek Bias Larutan}

\begin{abstract}
Abstrak
Penghitung foton tunggal berkorelasi waktu adalah sistem yang awalnya didesain dalam mengukur lifetime pendaran dari material yang berpendar. Sistem ini dirancang khusus untuk pengujian riset dasar fotonika dan ilmu fotonika yang biasanya dilakukan di dalam laboratorium. Selain itu, penghitung foton tunggal berkorelasi waktu dapat digunakan untuk mengukur sifat optik material yang sederhana dan lebih praktis, seperti indeks bias. Namun, karena sistem ini tidak dirancang untuk aplikasi praktis, maka diperlukan modifikasi pengaturan dan perhitungan sederhana. Dalam penelitian ini, kami menggunakan penghitung foton tunggal berkorelasi waktu untuk mengukur indeks bias larutan sodium klorida. Pengukuran dilakukan dengan menggunakan perhitungan waktu tempuh dari setiap pulsa laser pulsa picosekon. Pengukuran kami dilakukan pada konsentrasi natrium klorida yang berbeda yang memiliki indeks bias yang berbeda. Kami menemukan bahwa teknik pengukuran dan perhitungan kami mampu menghasilkan perhitungan kuantitatif indeks bias yang konsisten.
\end{abstract}

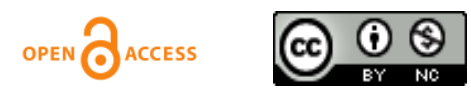


Kata Kunci: waktu tempuh, laser pulsa picosekon, indeks bias

PACS: 06.20.Jr, 06.60.Jn, 07.60.Hv, 42.50.Ar

(C) 2019 Jurnal Penelitian Fisika dan Aplikasinya (JPFA). This work is licensed under CC BY-NC 4.0

Article History: Received: August 9, $2019 \quad$ Approved with minor revision: September 25, 2019

Accepted: December 4, 2019 Published: December 31, 2019

How to cite: Isnaeni, Mulyawan RG, and Hakimi AR. Simple Application of Time Correlated Single Photon Counter of Picosecond Pulsed Laser for Measuring Refractive Index of Saline Solution. Jurnal Penelitian Fisika dan Aplikasinya (JPFA). 2019; 9(2): 105-113. DOI: https://doi.org/10.26740/jpfa.v9n2.p105-113.

\section{INTRODUCTION}

Photonics is one of the basic branches in Physics that concerns with the properties and transmission of photons. Nowadays, photonics is also used to study emitting nanoparticles. This branch is known as nanophotonics $[1,2]$. In nanophotonics, one of the important measurements is Time Correlated Single Photon Counter (TCSPC). This system is designed to measure fluorescence lifetime of emitting nanoparticles $[3,4]$.

TCSPC is a popular and established measurement system to measure fluorescence lifetime. The fluorescence lifetime, or known as time-resolved photoluminescence, is unique characteristic of emitting molecules and can thus be used to characterize the emitting samples [4,5]. Special energy transfer between nanoparticles, including Förster Resonance Energy Transfer [6], quenching [7,8], charge transfer [9-11], solvation dynamics [12,13], or molecular rotation are several major subjects of TCSPC study. The changes of the lifetime can also be used to observe local chemical environment or reaction mechanisms [14,15]. These are example of experiments that use TCSPC.

Basic operation of TCSPC is very simple. A picosecond laser produces pulsed laser with certain interval. This laser excites a sample that emits luminescence. TCSPC system measures time difference between the produced laser pulse and detected sample's luminescence [16,17]. TCSPC requires a defined start-time which is provided by the electronics system of laser pulse, and also a defined stop-time signal which is realized by detection of the luminescence. The measurement of this time delay is then repeated many times to get the statistical nature of the luminescent samples. The start-stop mechanism is then known as time of flight mechanism [18].

This time of flight mechanism can be modified, so that TCSPC system can be used for other measurements. Modification of original TCSPC system depends on particular application based on the users' expectation. Modifications include experimental setup modification and analysis modification. Certain application requires different modification. In this work, TCSPC application is selected to measure the refractive index of liquid. The use of this application is expected to provide alternative measurement system for the refractive index, besides the common popular principles such as Snell's Law [19,20] and Z-scan method [21].

Ordinary refractometer is a well-known device for measuring refractive index; however, this system consists of too much optics, such as prisms and lenses. The system is difficult to be implemented and modified for laboratory purpose [22,23]. Some researchers developed refractometer using optical fiber [23-25]. This system has shown good performance; however, the optical fiber is initially specially designed and it takes 
high cost for creating special optical fiber. The Snell's Law is the basic method to measure refractive indices. However, the accuracy of this method is limited since the angle determination is the crucial factor $[26,27]$. Based on previous works by several studies, thus it is asserted that accuracy and simple measurement system are two most fundamental factors in determining the refractive indices. All measurement systems mentioned above usually can only determine refractive index up to two digits. Improving accuracy up to three digits of refractive index using simple equipment is challenging and has never been achieved previously by the mentioned systems.

In this work, there are two significant improvements will be covered. First, modification was carried out to the TCSPC system to measure saline solution by using only simple and small amount of measured liquid. Only $100 \mathrm{~mm}$ length of chamber was used in this study. This length is very short and almost indistinguishable for speed of light. Second, this study measures the different refractive index of several saline solutions which have small refractive index differences. It is believed the accuracy can be improved from the measurement until three-digit refractive index.

The purposes of this research are mainly to modify the TCSPC system into refractive index measurement system and measure refractive indices of sodium chloride solutions for preliminary application of our system.

\section{METHOD}

The modified setup of TCSPC is described in Figure 1. All parts of TCSPC system was from PicoQuant [28]. Picosecond laser source is driven by laser driver. The laser source PicoQuant D800 was prepared that emits laser at wavelength $420 \mathrm{~nm}$ and adjustable power repetition rate. The laser was directed to a chamber, where sample solution was placed. The length of sample chamber was $100 \mathrm{~mm}$. The front and rear surface of the chamber was flat, and the laser was directed perpendicular to the surface of the chamber to avoid refraction angle in the liquid. After passing through sample chamber, the laser hit detector (MPD detector). Laser driver and signal from detector were connected to Picoharp-260 controller in computer. The distance between laser source and detector was $1 \mathrm{~m}$.

The TCSPC signal was recorded using TimeHarp software. The time difference $(\Delta t)$ of measured signals was recorded manually with and without sample. The time difference would be used to determine the measured refractive index. The measured refractive index was then compared to calculated refractive index from reference. All measurements were done in room temperature.

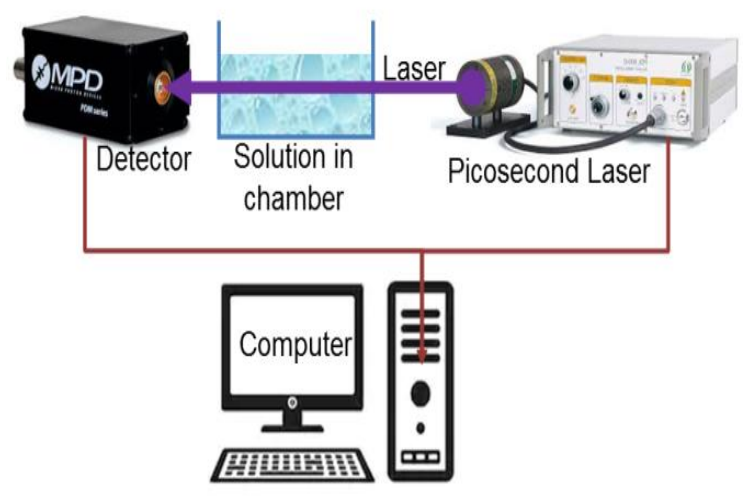

Figure 1. Modified setup of TCSPC for refractive index measurement

Sodium chloride $(\mathrm{NaCl})$ solution was prepared along with various concentration of sodium chloride $(0 \%, 5 \%, 10 \%, 20 \%, 40 \%$ and $70 \% \mathrm{w} / \mathrm{v})$. In order to make sodium chloride solution, sodium chloride powder from Sigma Aldrich was selected. In order to create $5 \%(\mathrm{w} / \mathrm{v})$ sodium chloride solution, 10 gram of sodium chloride in a glass beaker was mixed with water until the total volume was $200 \mathrm{~mL}$. The mixture was then put on a 
magnetic stirrer for about 10 minutes to make homogenous solution. For every measurement, it required approximately 150 $\mathrm{mL}$ solution to fill the chamber.

\section{III.RESULTS AND DISCUSSION}

The TCSPC system was modified for the refractive index measurement of sodium chloride. In order to determine refractive index using our modified TCSPC system, the following are some assumptions:

1. Speed of laser light in air is equal to speed of light in vacuum $(c)$.

2. The length of sample chamber is fixed 100 $\mathrm{mm}$. The thickness of chamber's wall is neglected.

The measurement of refractive index using the modified TCSPS system was based on time of flight (known as time difference) of laser propagation with and without sample. Beside modification of TCSPC system, modified simple analysis was employed to obtain measured refractive index. In this work, the time difference $(\Delta t)$ is defined as in Equation (1).

$$
\Delta t=t_{s}-t_{0}
$$

where $t_{o}$ is recorded signal time of laser without sample and $t_{s}$ is recorded signal time of laser with sample.

It is well-known that refractive index $(\eta)$ is defined in Equation (2).

$$
\begin{aligned}
& \eta=\frac{c}{v} \\
& v=\frac{x}{t}
\end{aligned}
$$

where $c$ is speed of light in vacuum, $v$ is speed of light in medium (sample), $x$ is propagation distance and $t$ is propagation time. The difference of laser propagation with and without laser is only in sample chamber $(x=100 \mathrm{~mm})$. This sample medium results time difference $\Delta t$. The time difference is inserted to the Equation (3) to get Equation (4).

$$
\Delta \eta=\frac{c \Delta t}{x}
$$

As it is known that $\Delta \eta$ is defined as follow in Equation (5).

$$
\Delta \eta=\eta_{\text {sample }}-\eta_{\text {air }}
$$

By assuming $\eta_{\text {air }}=1$ and combining Equations (5) and (4), simple equation is obtained to determine the refractive index of sample $\left(\eta_{\text {sample }}\right)$ in Equation (6).

$$
\eta_{\text {sample }}=\frac{c \Delta t}{x}+1
$$

Figure 2 shows example of time of flight measurement of picosecond pulsed laser obtained from TCSPS system. The black curve is TCSPC signal without sample and the red curve is TCSPC with solution sample. The time difference $\Delta t$ was defined between the peak of black curve and the peak of red curve. It was also noticeable that red curve is wider than black curve. This is due to liquid effect that might delay laser propagation. However, this effect does not affect the determination of $\Delta t$ since only time recorded at peak of each curves was used.

This time difference is then used in Equation (6) to determine the measured refractive index. The measurement was conducted for four times to obtain average measured refractive index and standard deviation of measurement for every sample.

Figure 3 shows the measured refractive index of various sodium chloride concentrations using our modified TCSPC system including error bar, which is the standard deviation of measurement. It was found that higher concentration of sodium chloride yields higher refractive index. It was also found the error bars, which indicate deviation of measurements, were ranging from 0.012 to 0.034 or from $0.69 \%$ to $2.13 \%$, respectively. This small error bar indicates that our measurement is repeatable and consistent. 


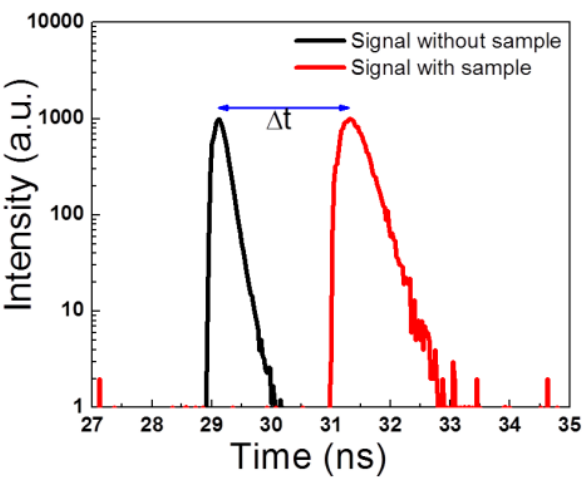

Figure 2. Example of TCSPC Signal Used to

Measure Refractive Index in this Work

The error of measurement is probably due several factors. First, although the liquid seems to be stable and static without movement, water and molecules inside might moving to external pressure and temperature. This small Brownian motion affects the laser propagation slightly. Second, the time resolution of TCSPC system is only 25 picoseconds. It means that the smallest time difference that can be measured is only 25 picoseconds. The length of chamber sample used was only $100 \mathrm{~mm}$ which causes error of refractive index around 0.01 (or two digits) of refractive index. This makes the measured refractive index is valid until two digits only.

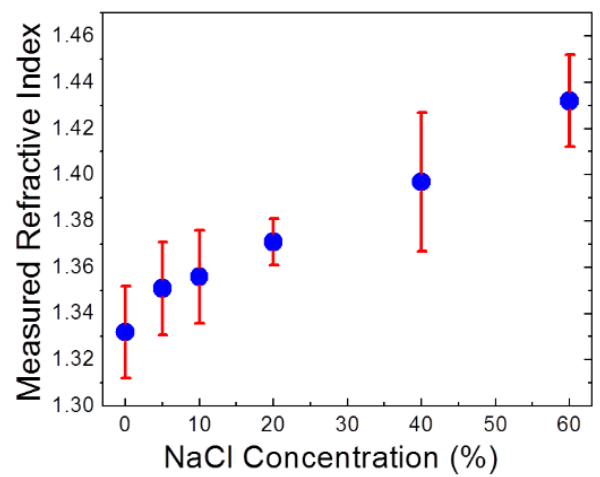

Figure 3. Measured Refractive Index of Sodium

Chloride with Different Concentrations

Table 1. Measured and Calculated Refractive Index

\begin{tabular}{cccccc}
\hline Samples & $\begin{array}{c}\text { Sodium chloride } \\
\text { Concentration (\%) }\end{array}$ & $\begin{array}{c}\text { Measured } \\
\text { Refractive Index }\end{array}$ & $\begin{array}{c}\text { Calculated Refractive } \\
\text { Index (Reference) }\end{array}$ & \multicolumn{2}{c}{ Refractive Index Difference } \\
\cline { 5 - 6 } & 0 & 1.332 & 1.334 & 0.002 & in number \\
\hline 2 & 5 & 1.352 & 1.343 & 0.008 & 0.14 \\
3 & 10 & 1.356 & 1.352 & 0.004 & 0.29 \\
4 & 20 & 1.371 & 1.368 & 0.003 & 0.22 \\
5 & 40 & 1.397 & 1.396 & 0.001 & 0.07 \\
6 & 70 & 1.432 & 1.419 & 0.013 & 0.92 \\
\hline
\end{tabular}

However, in order to overcome this limitation, longer chamber sample length could possibly be used in the future experiment. By simple calculation, $1 \mathrm{~m}$ length of chamber sample can give error until three digits $(0.001)$ of refractive index. This kind of system is suitable for high precision of refractive index measurement.

In order to validate the measurement, reference value of refractive indices was used for the sodium chloride. Tan, et al were able to calculate refractive index of sodium chloride as function of temperatures and concentrations as follow in Equation (7) $[29,30]$.

$$
\begin{aligned}
\eta=1.3373+ & \left(1.7682 \cdot 10^{-3}\right) c \\
& -\left(5.8 \cdot 10^{-6}\right) c^{2} \\
& -\left(1.3531 \cdot 10^{-4}\right)(T \\
& -273.15) \\
& -\left(5.1 \cdot 10^{-8}\right)(T-273.15)^{2}
\end{aligned}
$$

where $c$ is concentration of sodium chloride in percentage (\%) and $T$ is temperature in Kelvin.

Since all experiments were conducted in room temperature $(T=298 \mathrm{~K})$, thus the refractive index of sodium chloride can be calculated at different concentrations. The value of refractive indices calculated using Equation (7) is shown in Table 1 as the 
calculated refractive index (reference). The test results were compared with the previous tests. The results of the tests were compared with the calculations (Equation (7)) of other researchers. In this article, the test results are referred as "measured refractive indexes", while the comparison results are referred to as "calculated refractive indexes". The results of the comparison have been presented clearly in table 1. It is assumed that this comparison is the analysis of error for this work. The results of this study have accuracy down to 3 digits. Thus, it is considered better than the conventional system that only have accuracy down to 2 digits [22, 23]. This study can have similar accuracy to calculation previous works [29]. In terms of complexity of the experimental system, the system in this study is much simpler than the common fiber optics-based refractive index system [24].

Table 1 shows the measured refractive indices obtained using the modified TCSPS system, calculated refractive index using Equation (7) and the refractive index difference. It was found that the measured refractive index is very similar to the calculated refractive index. The difference is less than $1 \%$ error of differences. This finding indicates that the modified TCSPC system in this study is believed to be able to measure refractive index of liquid.

This study provides simple and accurate measurement of refractive indices of liquid samples. In the future, the measurement system can use for various liquid. Furthermore, this system can be integrated in other fields such oil companies and maritime industries, since or system is compact, portable and required only small space.

\section{CONCLUSION}

The modified TCSPS system is successful to measure the refractive index of liquid based on time of flight of TCSPS signal curves. A series of measurement were also carried out to the sodium chloride with different concentration from $0 \%$ until $70 \%$. It was found that the measured refractive index is reapetable with small measurement deviation. It was also asserted that the measured refractive index is very similar (with more than $99 \%$ similarity) to calculated refractive index as reference value. The modified TCSPS system in this study can be applied and improved in the future to obtain more precise value of refractive index.

\section{ACKNOWLEDGMENT}

This work is fully supported DIPA Project from Research Center for Physics Lembaga Ilmu Pengetahuan Indonesia Number 8442/ 1PT.1/A/2019.

\section{REFERENCES}

[1] Koenderink AF, Alu A, and Polman A. Nanophotonics: Shrinking Light-Based Technology. Science. 2015; 348(6234): 516-521. DOI:

http://dx.doi.org/10.1126/science.1261243.

[2] Polman A, Kociak M, and Abajo FJGD. Electron-Beam Spectroscopy for Nanophotonics. Nature Materials. 2019; 18: 1158-1171. DOI: http://dx.doi.org/10.1038/s41563-019-04091 .

[3] Shcheslavskiy V, Morozov P, Divochiy A, Vakhtomin Yu, Smirnov K, and Becker W. Ultrafast Time Measurements by Time-Correlated Single Photon Counting Coupled with Superconducting Single Photon Detector. Review of Scientific Instruments. 2016; 87: 053117. DOI: http://dx.doi.org/10.1063/1.4948920. 
Jurnal Penelitian Fisika dan Aplikasinya (JPFA), 2019; 9(2): 105-113

[4] Hirvonen LM and Suhling K. Wide-field TCSPC: Methods and Applications. Measurement Science and Technology. 2017; 28(1): 1-19. DOI:

http://dx.doi.org/10.1088/1361-6501/28/1/01 2003.

[5] Maccarone A, McCarthy A, Ren X, Warburton RE, Wallace AM, Moffat J, Petillot Y,and Buller GS. Underwater Depth Imaging using Time-Correlated Single-Photon Counting. Optic Express. 2015; 23(16): 33911-33926. DOI: http://dx.doi.org/10.1364/OE.23.033911.

[6] Rudkouskaya A, Sinsuebphon N, Intes X, Mazurkiewicz JE, and Barroso $M$. Fluorescence Lifetime FRET Imaging of Receptor-Ligand Complexes in Tumor Cells In Vitro and In Vivo. Proceedings of Multiphoton Microscopy in the Biomedical Sciences XVII. 2017; 10069: 1006917. DOI: https://doi.org/10.1117/12.2258231.

[7] Radziuk D, Möhwald H. Ultrasonically Treated Liquid Interfaces for Progress in Cleaning and Separation Processes. Physical Chemistry Chemical Physics. 2016; 18(1): 21-46. DOI:

http://dx.doi.org/10.1039/C5CP05142H.

[8] Shao J, Zhu S, Liu H, Song Y, Tao S, and Yang B. Full-Color Emission Polymer Carbon Dots with Quench-Resistant Solid-State Fluorescence. Advanced Science. 2017; 4(12): 1700395. DOI:

http://dx.doi.org/10.1002/advs.201700395.

[9] Proppe AH, Xu J, Sabatini RP, Fan JZ, Sun B, Hoogland S, Kelley So, Voznyy O, and Sargent EH. Picosecond Charge Transfer and Long Carrier Diffusion Lengths in Colloidal Quantum Dot Solids. Nano Letters. 2018; 18(11): 7052-7059. DOI:

http://dx.doi.org/10.1021/acs.nanolett.8b030 20.

[10] Yu J, Xu C, Tian Z, Lin Y, and Shi Z. Facilely synthesized N-doped Carbon Quantum Dots with High Fluorescent Yield for Sensing $\mathrm{Fe}^{3+}$. New Journal of Chemistry.
2016; 40(3): 2083-2088. DOI:

http://dx.doi.org/10.1039/C5NJ03252K.

[11] Yu P, Wen X, Toh Y-R, Lee Y-C, Huang K-Y, Huang S, Shrestha S, Conibeer G, and Tang

J. Efficient Electron Transfer in Carbon Nanodot-Graphene Oxide Nanocomposites. Journal of Materials Chemistry C. 2014; 2(16): 2894-2901. DOI:

http://dx.doi.org/10.1039/c3tc32395a.

[12] Simkovitch R, Shomer S, Gepshtein R, and Huppert D. How Fast can a Proton-Transfer Reaction be Beyond the Solvent-Control Limit? The Journal of Physical Chemistry B. 2015; 119(6): 2253-2262. DOI:

http://dx.doi.org/10.1021/jp506011e.

[13] Samanta A. Solvation Dynamics in Ionic Liquids: What We Have Learned from the Dynamic Fluorescence Stokes Shift Studies. The Journal Physical Chemistry Letters. 2010; 1(10): 1557-1562. DOI: http://dx.doi.org/10.1021/jz100273b.

[14] Hanson K, Brennaman MK, Ito A, Luo H, Song W, Parker KA, Ghosh R, Norris MR, Galsson CRK, Concepcion JJ, Lopez R, and Meyer TJ. Structure-Property Relationships in Phosphonate-Derivatized, $\mathrm{Ru}$ II Polypyridyl Dyes on Metal Oxide Surfaces in an Aqueous Environment. The Journal Physical Chemistry C. 2012; 116(28): 14837-14847. DOI:

http://dx.doi.org/10.1021/jp304088d.

[15] Thangaraj B, Jolley CC, Sarrou I, Bultema JB, Greyslak J, Whitelegge JP, Lin S, Kouřil R, Subramanyam R, Boekema EJ, and Fromme P. Efficient Light Harvesting in a Dark, Hot, Acidic Environment: The Structure and Function of PSI-LHCI from Galdieria sulphuraria. Biophysical Journal. 2011; 100(1): 135-413. DOI:

http://dx.doi.org/10.1016/j.bpj.2010.09.069.

[16] Lamb RA. A Technology Review of Time-of-Flight Photon Counting for Advanced Remote Sensing. Proceedings of Advanced Photon Counting Techniques IV. 2010; 7681: 768107. DOI: 
http://dx.doi.org/10.1117/12.852138.

[17] Chunnilall CJ, Degiovanni IP, Kück S, Müller I, and Sinclair AG. Metrology of Single-Photon Sources and Detectors: a Review. Optical Engineering. 2014; 53(8): 081910. DOI:

http://dx.doi.org/10.1117/1.OE.53.8.081910.

[18] Chen S, Liu D, Zhang W, You L, He Y, Zhang W, Yang X, Wu G, Ren M, Zeng H, Wang Z, Xie X, and Jiang M. Time-of-Flight Laser Ranging and Imaging at $1550 \mathrm{~nm}$ Using Low-Jitter Superconducting Nanowire Single-Photon Detection System. Applied Optics. 2013; 52(14): 3241-3245. DOI: http://dx.doi.org/10.1364/AO.52.003241.

[19] Jeong D-E, Han D-S, and Kim S-K. Refractive Index and Snell's Law for Dipole-Exchange Spin Waves in Restricted Geometry. SPIN. 2011; 1(1): 27-31. DOI: http://dx.doi.org/10.1142/S20103247110000 $\underline{45}$.

[20] Seow YC, Lim SP, Khoo BC, and Lee HP. An Optofluidic Refractive Index Sensor Based on Partial Refraction. Sensors and Actuators B: Chemical. 2010; 147(2): 607-611. DOI:

http://dx.doi.org/10.1016/j.snb.2010.03.076.

[21] Zhang H, Virally S, Bao Q, Kian Ping L, Massar S, Godbout N, and Kockaert P. Z-Scan Measurement of the Nonlinear Refractive Index of Graphene. Optics Letters. 2012; 37(11): 1856-1858. DOI: http://dx.doi.org/10.1364/OL.37.001856.

[22] Egan PF, Stone JA, Ricker JE, Hendricks JH, and Strouse GF. Cell-Based Refractometer for Pascal Realization. Optics Letters. 2017; 42(15): 2944-2947. DOI:

http://dx.doi.org/10.1364/OL.42.002944.

[23] Zhou W, Zhou Y, Albert J. A True Fiber Optic Refractometer. Laser and Photonics Reviews. 2017; 11(1): 1600157. DOI: http://dx.doi.org/10.1002/lpor.201600157.
[24] Chiavaioli F, Gouveia CAJ, Jorge PAS, and Baldini F. Towards a Uniform Metrological Assessment of Grating-Based Optical Fiber Sensors: From Refractometers to Biosensors. Biosensors. 2017; 7(2): 1-29. DOI: http://dx.doi.org/10.3390/bios7020023.

[25] Wang Q, Zhao W-M. A Comprehensive Review of Lossy Mode Resonance-Based Fiber Optic Sensors. Optics and Lasers in Engineering. 2018; 100: 47-60. DOI: https://doi.org/10.1016/j.optlaseng.2017.07. 009.

[26] Rivera-Ortega U, Hernández-Gómez CR, Vega-Torres G, Lopez-Medina ME. Simple apparatus to calculate the refractive index of liquids based on Snell's law. Measurement. 2019; 134: 658-661. DOI:

https://doi.org/10.1016/j.measurement.2018. 10.037.

[27] Rivera-Ortega U, Hernandez-Gomez CR, and Vega-Torres G. Educational Opto-Mechatronic Apparatus to Calculate the Refractive Index of Liquids Based on Snell's Law. Proceeding of Fifteenth Conference on Education and Training in Optics and Photonics: ETOP 2019 (Optical Society of America). 2019; 11143. Available from:

https://www.osapublishing.org/abstract.cfm? uri=ETOP-2019-11143 11.

[28] Wahl M and Orthaus-Müller S. Time Tagged Time-Resolved Fluorescence Data Collection in Life Sciences. Berlin: PicoQuant; 2015. Available from: https://www.imaging-git.com/applications/ti me-tagged-time-resolved-fluorescence-datacollection-life-sciences.

[29] Tan CY and Huang YX. Dependence of Refractive Index on Concentration and Temperature in Electrolyte Solution, Polar Solution, Nonpolar Solution, and Protein Solution. Journal of Chemical Engineering Data. 2015; 60(10): 2827-2833. DOI: http://dx.doi.org/10.1021/acs.jced.5b00018. 
Jurnal Penelitian Fisika dan Aplikasinya (JPFA), 2019; 9(2): 105-113

[30] Radhakrishnan R, Gallais L, and Monneret S.

Wavefront Sensing Applied to Determine the

Temperature Dependence of the Refractive

Index of Liquids. Applied Optics. 2019;

58(13): 3646-3651. DOI:

http://dx.doi.org/10.1364/AO.58.003646. 